\title{
Oxidation of Hydrocarbons Catalyzed by $\pi-\mathrm{C}_{3} \mathrm{H}_{5} \mathrm{Fe}(\mathrm{CO}){ }_{3} \mathrm{Br}$
}

\author{
Yasukazu Ohkatsu, Toshio OkuYama, and Tetsuo Osa \\ Department of Synthetic Chemistry, Faculty of Engineering, \\ University of Tokyo (Bunkyo-ku, Tokyo)
}

\begin{abstract}
It was found that $\pi-\mathrm{C}_{3} \mathrm{H}_{5} \mathrm{Fe}(\mathrm{CO})_{3} \mathrm{Br}$ catalyzed the autoxidation of hydrocarbons. The active species of the catalyst was kinetically estimated to be an oxygen complex, namely $\pi-\mathrm{C}_{3} \mathrm{H}_{5} \mathrm{Fe}(\mathrm{CO})_{3} \mathrm{O}_{2}$, which was formed by the reaction of $\pi-\mathrm{C}_{3} \mathrm{H}_{5} \mathrm{Fe}(\mathrm{CO})_{3} \mathrm{Br}$ with oxygen. The oxygen activated on the $\pi$-allyl complex was able to undergo hydrogen abstraction reaction or addition reaction to the double bond of substrates.
\end{abstract}

It is well known that oxygen molecule cos ordinated to some organometallic complexes is activated to some extent. Some of oxygen complexes have been successfully investigated to oxidize organic substrates such as phosphines and isonitriles ${ }^{1) \sim 3}$. There have been, however, available only a few reports concerned with direct oxidation of hydrocarbons using these complexes as catalyst, Blum et al. ${ }^{4}$. oxidized ethylbenzene, tetralin, and related hydrocarbons using $\mathrm{Rh}(\mathrm{CO}) \mathrm{Cl}\left(\mathrm{PPh}_{3}\right)_{3}$. The rate of auto= xidation was found to be much higher in the presence of the Rh complex than that of noncatalytic reaction. Blum concluded that an oxygen complex derived from $\mathrm{Rh}(\mathrm{CO}) \mathrm{Cl}\left(\mathrm{PPh}_{3}\right)_{3}$ catalyzed the autoxidation reaction. Fine et al., ${ }^{5)}$ however, criticized the above conclusion and presented other mechanisms in which the $\mathrm{Rh}$ complex did not work as the oxygen com= plex, but it decomposed the hydroperoxide formed by a spontaneous oxidation process, which resulted in the acceleration of autoxida= tion at higher temperatures. Fine et al. found in the reaction mixture of diphenylmethane oxidation that only a smaller amount of the hydroperoxide was accumulated in the presence of the Rh complex compared with the case of uncatalyzed oxidation. They concluded that the major role of the complex should be in an acceleration of the homolytic decomposition of the hydroperoxide. Although oxidations of cyclohexene with a Vaska's complex ${ }^{6}$ and those of styrene with rhodium and iridium complexes are also reported, there is no clear evidence which may indicate the direct oxidation mech= anism by oxygen complexes.

We have already reported that metal poly (phthalocyanines) ${ }^{7 \sim 9)}$ and porphyrins ${ }^{10), 11)}$ acti= vate oxygen molecule in the form of superoxide ion $\left(\mathrm{O}_{2}^{-}\right)$, which directly abstracts the hydrogen atom from cumene, ${ }^{7)}$ acrolein ${ }^{8}$ or acetaldehyde ${ }_{9) \sim 11)}$ to initiate autoxidation. The $\pi-\mathrm{C}_{3} \mathrm{H}_{5} \mathrm{Fe}$ $(\mathrm{CO})_{3} \mathrm{Br}$ was reported to activate oxygen in a similar form $\left(\pi-\mathrm{C}_{3} \mathrm{H}_{5} \mathrm{Fe}(\mathrm{CO})_{3}\left(\mathrm{O}_{2}\right)\right)^{12)}$.

The oxidation reactions of hydrocarbons using $\pi-\mathrm{C}_{3} \mathrm{H}_{5}-\mathrm{Fe}(\mathrm{CO})_{3} \mathrm{Br}$ will be reported in this paper.

\section{Experimental}

Materials : $\pi-\mathrm{C}_{3} \mathrm{H}_{5} \mathrm{Fe}(\mathrm{CO})_{3} \mathrm{Br}$ was prepared as described elsewhere. ${ }^{13), 14)}$ Oxygen was used after drying. Substrates to be oxidized were purified by treatment through a column packed with activated alumina and/or fractional distil= lation. Acetone was purified by a conventional method. Chlorobenzene was distilled after treating with sulfuric acid, washing completely with water, and drying. 2,6-Di-tert-butyl-4methylphenol (BMP) as a free radical trapping agent was purified by recrystallization.

Procedures : An amount of oxygen absorbed was measured according to the method using a Toshiba-Beckmann's Dissolved Oxygen Ana= 
lyzer Model 777 or by means of a transducer of differential pressure.

Oxidation products were analyzed qualita $=$ tively and quantitatively by GLC. Hydrogen peroxide, hydroperoxide, and peroxides were fractionally titrated by the method described in the literature ${ }^{15}$.

\section{Results and Discussion \\ Autoxidation initiated by the hydrogen abstraction.}

As shown in Figs. -1 and $-2, \pi-\mathrm{C}_{3} \mathrm{H}_{5} \mathrm{Fe}(\mathrm{CO})_{3}$ $\mathrm{Br}$ catalyzed a liquid-phase oxidation of $1,4-$ cyclohexadiene (Curve 1) in contrast with ferric and ferrous bromides. As soon as BMP was added during this oxidation process, the absorps tion of oxygen ceased (Curve 2). When BMP was present from the beginning in the reaction solution containing $\pi-\mathrm{C}_{3} \mathrm{H}_{5} \mathrm{Fe}(\mathrm{CO})_{3} \mathrm{Br}$ and 1 , 4cyclohexadiene, the oxidation was completely inhibited (Curve 3). These facts mean that the oxidation is a chain reaction (autoxidation) which is initiated by $\pi-\mathrm{C}_{3} \mathrm{H}_{5} \mathrm{Fe}(\mathrm{CO})_{3} \mathrm{Br}$ as catalyst.

The active species in the catalytic reactions of $\pi-\mathrm{C}_{3} \mathrm{H}_{5} \mathrm{Fe}(\mathrm{CO})_{3} \mathrm{Br}$ was considered to be iron bromides or other iron compounds formed

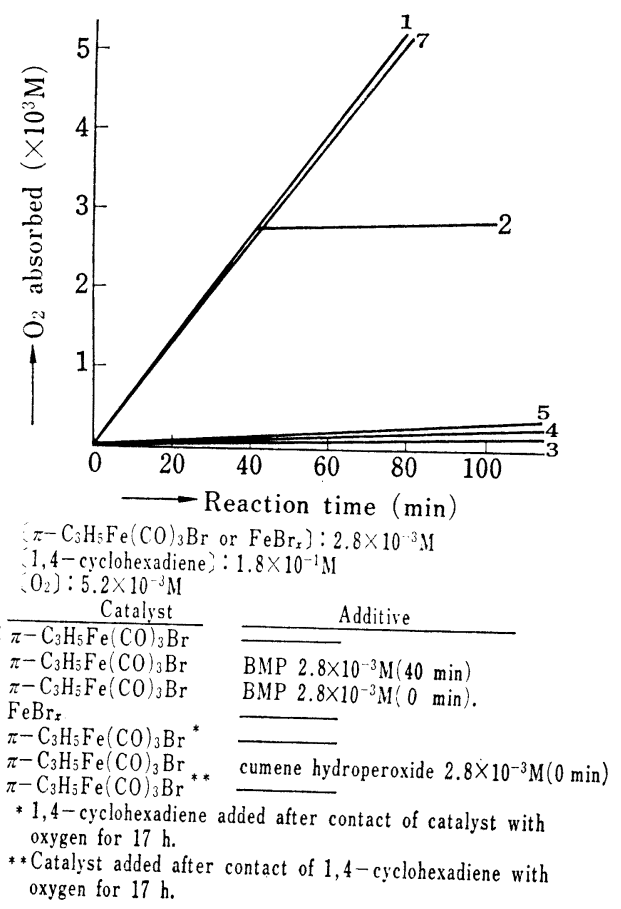

Fig.-1 Oxidation of 1,4-cyclohexadiene in chloro= benzene at $40^{\circ} \mathrm{C}$.

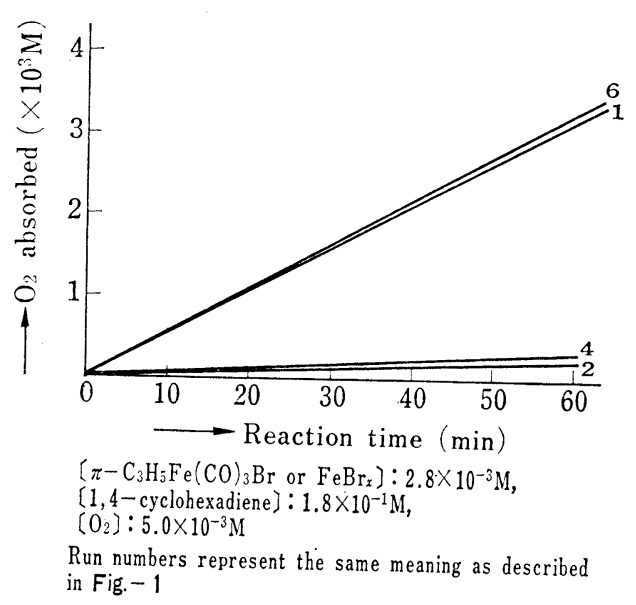

Fig.-2 Oxidation of 1,4-cyclohexadiene in acetone at $40^{\circ} \mathrm{C}$.

through the oxidative decomposition of the $\pi$ allyl complex. None of them, however, did exhibit catalytic activity as shown by Curves 4 and 5, respectively. It is also seen in Fig. -2 that the rate of oxygen absorption was not affected by cumene hydroperoxide added (Curve 6)*1) Furthermore, the rate of oxygen abo sorption was almost the same as that under conditions for Curve 1 even when $\pi-\mathrm{C}_{3} \mathrm{H}_{5} \mathrm{Fe}$ $(\mathrm{CO})_{3} \mathrm{Br}$ was added to the reaction mixture after a preliminary contact of 1,4-cyclohexa= diene with oxygen for $17 \mathrm{~h}$ (Curve 7 ). If the Haber-Weiss mechanism was valid, the $\pi$ $\mathrm{C}_{3} \mathrm{H}_{5} \mathrm{Fe}(\mathrm{CO})_{3} \mathrm{Br}$ would have initiated the oxidation reaction by the homolytic decompos sition of hydroperoxides added and formed by a spontaneous oxidation of 1,4-cyclohexadiene, and Curves 6 and 7 would show a different shape from Curve 1 .

The catalytic action of $\pi-\mathrm{C}_{3} \mathrm{H}_{5} \mathrm{Fe}(\mathrm{CO})_{3} \mathrm{Br}$ can also be explained by the kinetic treatment of the oxidation reaction. The dependency of the concentration of 1,4-cyclohexadiene (Fig.3-a), $\pi-\mathrm{C}_{3} \mathrm{H}_{5} \mathrm{Fe}(\mathrm{CO})_{3} \mathrm{Br}$ (Fig. -3-b), and oxy= gen (Fig.-3-c) on the rate of oxidation was found to be as follows:

$$
\begin{aligned}
-d\left[\mathrm{O}_{2}\right] / d t & =k_{1}[1,4 \text {-cyclohexadiene }]^{1.45}\left[\mathrm{O}_{2}\right]^{0.51} \\
& \times\left[\pi-\mathrm{C}_{3} \mathrm{H}_{5} \mathrm{Fe}(\mathrm{CO})_{3} \mathrm{Br}\right]^{0.45}
\end{aligned}
$$

This equation can be compared with the general formula for the autoxidation reaction :

*1) The $\pi$-allyl complex $\left(2.8 \times 10^{-3} \mathrm{M}\right)$ decomposed no cumene hydroperoxide $(1.0 \mathrm{M})$ in chloroben= zene at $40^{\circ} \mathrm{C}$, and a little hydrogen peroxide $(1.0 \mathrm{M})$ in chlorobenzene at $40^{\circ} \mathrm{C}$ for $2 \mathrm{~h}$. 


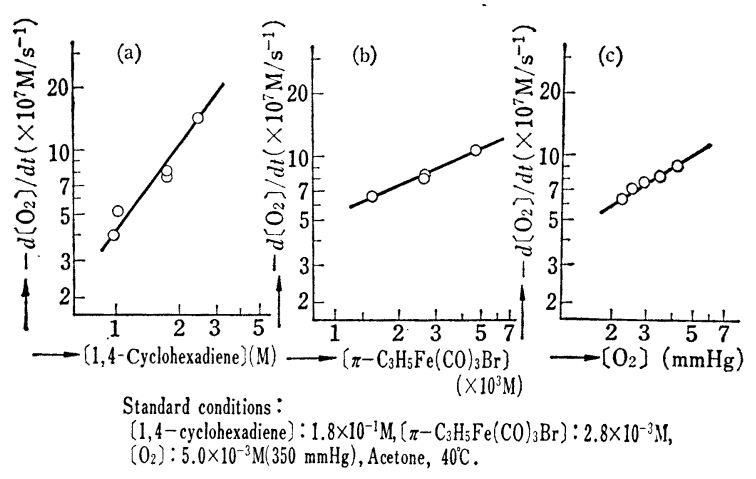

Fig.-3 Dependence of rate of oxygen absorbed on the concns. of 1,4-cyclohexadiene, $\pi-\mathrm{C}_{3} \mathrm{H}_{5} \mathrm{Fe}(\mathrm{CO})_{3} \mathrm{Br}$, and $\mathrm{O}_{2}$.

$$
\begin{aligned}
-d\left[\mathrm{O}_{2}\right] / d t & =\left[k_{\mathrm{p}} /\left(2 k_{\mathrm{t}}\right)^{1 / 2}\right] \\
& \times[1,4 \text {-cyclohexadiene }] R_{\mathrm{i},{ }_{1}{ }^{1 / 2}}
\end{aligned}
$$

in which $R i$ means the rate of initiation, and produces $R_{\mathrm{i}}$ as follows:

$$
\begin{aligned}
R_{\mathrm{i}, 1}=k_{1}{ }^{\prime}[1,4 \text {-cyclohexadiene }]^{0.9}\left[\mathrm{O}_{2}\right]^{1.02} \\
\\
\times\left[\pi-\mathrm{C}_{3} \mathrm{H}_{5} \mathrm{Fe}(\mathrm{CO})_{3} \mathrm{Br}\right]^{0.9} \\
=k_{1}[1,4 \text {-cyclohexadiene }]\left[\mathrm{O}_{2}\right] \\
\times\left[\pi-\mathrm{C}_{3} \mathrm{H}_{5} \mathrm{Fe}(\mathrm{CO})_{3} \mathrm{Br}\right]
\end{aligned}
$$

Considering that 1,4-cyclohexadiene was little oxidized in absence of $\pi-\mathrm{C}_{3} \mathrm{H}_{5} \mathrm{Fe}(\mathrm{CO})_{3} \mathrm{Br}$ under such conditions as described in Fig.-3. eg. (B) for the initiation reaction is reasonably explained by assuming that the activated oxygen molecule $\left(\mathrm{O}_{2}^{-}\right)$in $\pi-\mathrm{C}_{3} \mathrm{H}_{5} \mathrm{Fe}(\mathrm{CO})_{3} \mathrm{O}_{2}$ complex ${ }^{* 2)}$ formed by the reaction between the original $\pi$-allyl complex and oxygen abstracts the hy= drogen atom from 1,4-cyclohexadiene to initiate the chain reaction :

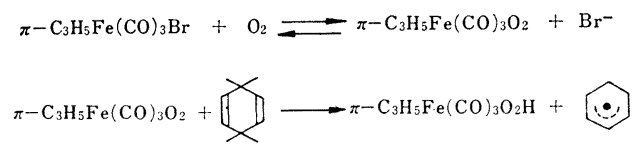

According to Howard and Ingold, ${ }^{16)}$ who studied the autoxidation reaction of 1,4 -cyclos hexadiene in detail, neither phenol nor a hydroperoxide was formed on any detectable

*2) The $\mathrm{O}_{2}$ complex was estimated by electros chemical measurements that the bromine of $\pi$ $\mathrm{C}_{3} \mathrm{H}_{5} \mathrm{Fe}(\mathrm{CO})_{3} \mathrm{Br}$ was substituted by oxygen molecule, resulting in the formation of negatively charged and activated oxygen molecule on the complex. ${ }^{12)}$ amounts. Instead, they obtained benzene and hydrogen peroxide in high yields. There was also no evidence of first-order chain termination process. On the basis of these observations, they could confirm the Russell's suggestion :

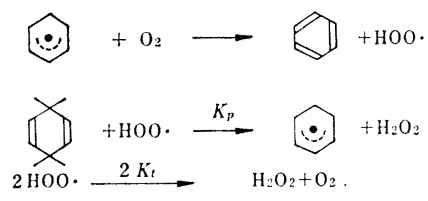

We also obtained benzene (83 930' based on absorbed oxygen and hydrogen peroxide $(60 \sim$ $66 \%$ ) in the oxidation reaction carried out under conditions : $[1,4$-cyclohexadiene $]=1.8 \times$ $10^{-1} \mathrm{M}, \quad\left[\pi-\mathrm{C}_{3} \mathrm{H}_{5} \mathrm{Fe}(\mathrm{CO})_{3} \mathrm{Br}\right]=2.8 \times 10^{-3} \mathrm{M}$, and $40^{\circ} \mathrm{C}$. Phenol and the hydroperoxide were not detected. We concluded that the Russell's mechanism can also be applied to our oxidation process of 1,4-cyclohexadiene catalyzed by $\pi$ $\mathrm{C}_{3} \mathrm{H}_{5} \mathrm{Fe}(\mathrm{CO})_{3} \mathrm{Br}$ complex.

Several hydrocarbons were also oxidized in the same manner (Table-1). The hydrogenabstracting capacity of $\pi-\mathrm{C}_{3} \mathrm{H}_{5} \mathrm{Fe}(\mathrm{CO})_{3} \mathrm{O}_{2}$ seems to be controlled by the dissociation energy of the carbon-hydrogen bond of substrates to be oxidized. The $\pi-\mathrm{C}_{3} \mathrm{H}_{5} \mathrm{Fe}(\mathrm{CO})_{3} \mathrm{Br}$ can catalyzed the autoxidation of substrates having bond energy below $76 \mathrm{kcal} / \mathrm{mol}$, while it cannot abs stract the hydrogen atom from substrates above $79 \mathrm{kcal} / \mathrm{mol}$. However, a substrate having het= ero-atoms such as aldehyde cannot be discussed in terms of the common criteria with those of hydrocarbons mentioned above.

This exception may ascribed to the lowering of bond dissociation energy by a possible inter= action of the hetero-atom with the ion complex. It was reported that electrogenerated superoxide ion $\left(\mathrm{O}_{2}^{-}\right)$had the hydrogen-abstracting ability enough for hydrocarbons such as cyclohexane $(93 \mathrm{kcal} / \mathrm{mol})$ and toluene $\left.(87 \mathrm{kcal} / \mathrm{mol})^{17}\right)$, and the activated oxygen molecule on a metal poly(phthalocyanine) was able to catalyze the autoxidation of substrates having a bond energy below $83 \mathrm{kcal} / \mathrm{mol}$ such as cumene ${ }^{7)}$. The degree of eletron transfer in $\pi-\mathrm{C}_{3} \mathrm{H}_{5} \mathrm{Fe}(\mathrm{CO})_{3} \mathrm{O}_{2}$, therefore, is considered to be considerably small. 
Table-1 Oxidation of hydrocarbons using $\pi-\mathrm{C}_{3} \mathrm{H}_{5} \mathrm{Fe}(\mathrm{CO})_{3} \mathrm{Br}$ as catalyst

\begin{tabular}{|c|c|c|c|c|c|}
\hline Hydrocarbon & & Solvent & $\begin{array}{l}-d\left[\mathrm{O}_{2}\right] / d t \\
\times 10^{6} \mathrm{M} \cdot \mathrm{s}^{-1}\end{array}$ & $\begin{array}{l}\mathrm{D}\left(\mathrm{C}_{-} \mathrm{H}\right) \\
\mathrm{kcal} / \mathrm{mol}\end{array}$ & Remarks \\
\hline 1,4-Cyclohexadiene & $0.18 \mathrm{M}$ & Acetone & 0.80 & 71 & $\mathrm{a}$ \\
\hline " & $0.18 \mathrm{M}$ & Chlorobenzene & 1.18 & " & $\mathrm{b}$ \\
\hline "I & $5.6 \mathrm{M}$ & " & 392 & $" \prime$ & $\mathrm{c}$ \\
\hline \multirow[t]{2}{*}{9,10 -Dihydroanthracene } & $0.18 \mathrm{M}$ & Acetone & 0.55 & " & $\mathrm{a}$ \\
\hline & $1.0 \mathrm{M}$ & Chlorobenzene & 52.3 & " & $\mathrm{d}$ \\
\hline Methyl linoleate & $2.1 \mathrm{M}$ & II & 6.83 & 76 & $\mathrm{c}$ \\
\hline Allylbenzene & & " & 0.0 & 79 & $"$ \\
\hline Cumene & & $1 "$ & " & 79 & " \\
\hline Tetralin & & $1 "$ & $" 1$ & 82 & $" 1$ \\
\hline Benzaldehyde & & $" \prime$ & 71.5 & & $\mathrm{~b}$ \\
\hline$i$-Butyraldehyde & & $" 1$ & 107 & & $" \prime$ \\
\hline
\end{tabular}

\begin{tabular}{cc|c|c}
\hline Remarks & $\pi-\mathrm{C}_{3} \mathrm{H}_{5} \mathrm{Fe}(\mathrm{CO})_{3} \mathrm{Br}\left(\times 10^{3} \mathrm{M}\right)$ & $\mathrm{O}_{2}\left(\times 10^{3} \mathrm{M}\right)$ & Temp. $\left({ }^{\circ} \mathrm{C}\right)$ \\
\hline $\mathrm{a}$ & 2.8 & 5.0 & 40 \\
$\mathrm{~b}$ & $\prime \prime$ & 5.2 & 50 \\
$\mathrm{c}$ & 2.0 & 7.6 & 50 \\
$\mathrm{~d}$ & $\prime \prime$ & 7.6 & 11 \\
\hline
\end{tabular}

Autoxidation initiated by the addition of oxygen molecule activated by $\pi-\mathrm{C}_{3} \mathrm{H}_{5} \mathrm{Fe}-$ (CO) ${ }_{3} \mathrm{Br}$.

The oxidation of $\alpha$-methylstyrene was cata lyzed not by ferrous and ferric bromides, but only by $\pi-\mathrm{C}_{3} \mathrm{H}_{5} \mathrm{Fe}(\mathrm{CO})_{3} \mathrm{Br}$. In the latter case, the addition of BMP inhibited the oxidation completely. The rate law in the oxidation of $\alpha$-methylstyrene with $\pi-\mathrm{C}_{3} \mathrm{H}_{5} \mathrm{Fe}(\mathrm{CO})_{3} \mathrm{Br}$ was explained as follows :

$$
\begin{aligned}
-d\left[\mathrm{O}_{2}\right] / d t= & k_{2}[\alpha \text {-methylstyrene }]^{1.56}\left[\mathrm{O}_{2}\right]^{0.50} \\
& \times\left[\pi-\mathrm{C}_{3} \mathrm{H}_{5} \mathrm{Fe}(\mathrm{CO})_{3} \mathrm{Br}\right]^{0.56}
\end{aligned}
$$

(see, Figs. $-4-\mathbf{a}, \mathbf{b}$ and c). The results men= tioned above are similar to those obtained in

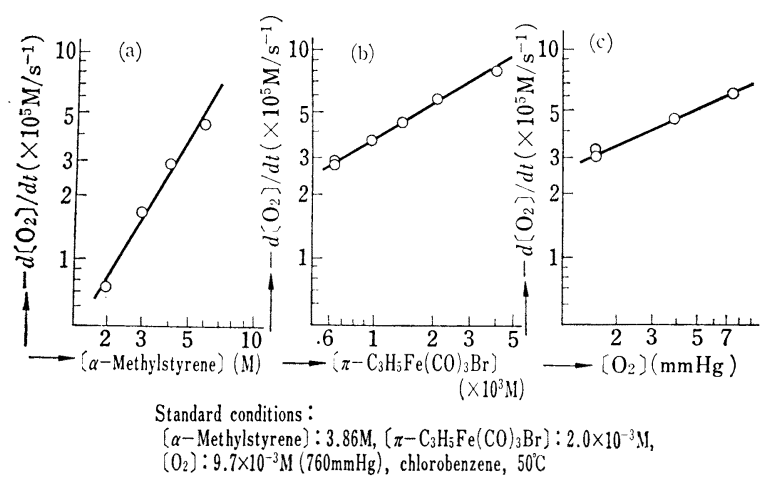

Fig.-4 Dependence of rate of oxygen absorbed on the concns. of $\alpha$-methylstyrene, $\pi-\mathrm{C}_{3} \mathrm{H}_{5} \mathrm{Fe}-$ $(\mathrm{CO})_{3} \mathrm{Br}$, or $\mathrm{O}_{2}$. the oxidation of 1,4-cyclohexadiene as described before. This fact means that the oxidation proceeds through an autoxidation mechanism and that the rate of initiation is expressed as eq. (D) :

$$
\begin{array}{r}
R_{\mathrm{i}, 2}=k_{2}{ }^{\prime}[\alpha-\text { methylstyrene }]\left[\mathrm{O}_{2}\right] \\
{\left[\pi-\mathrm{C}_{3} \mathrm{H}_{5} \mathrm{Fe}(\mathrm{CO})_{3} \mathrm{Br}\right]}
\end{array}
$$

The eq. (D) can be interpreted by the follow= ing initiation mechanism :

$$
\begin{aligned}
& \pi-\mathrm{C}_{3} \mathrm{H}_{5} \mathrm{Fe}(\mathrm{CO})_{3} \mathrm{Br}+\mathrm{O}_{2} \\
& \rightleftarrows \pi-\mathrm{C}_{3} \mathrm{H}_{5} \mathrm{Fe}(\mathrm{CO})_{3} \mathrm{O}_{2}+\mathrm{Br}^{-} \\
& \pi-\mathrm{C}_{3} \mathrm{H}_{5} \mathrm{Fe}(\mathrm{CO})_{3} \mathrm{O}_{2}+>\mathrm{C}=\mathrm{C}< \\
& \longrightarrow \pi-\mathrm{C}_{3} \mathrm{H}_{5} \mathrm{Fe}(\mathrm{CO})_{3} \mathrm{O}_{2}-\mathrm{C}-\mathrm{C} \text {. }
\end{aligned}
$$

Subsequently, the oxidation reaction proceeds as follows:

$$
\begin{gathered}
\pi-\mathrm{C}_{3} \mathrm{H}_{5} \mathrm{Fe}(\mathrm{CO})_{3} \mathrm{O}_{2}-\mathrm{C}-\mathrm{C} \cdot+\mathrm{O}_{2} \\
\longrightarrow \pi-\mathrm{C}_{3} \mathrm{H}_{5} \mathrm{Fe}(\mathrm{CO})_{3} \mathrm{O}_{2}-\mathrm{CO}_{2} \cdot \\
\pi-\mathrm{C}_{3} \mathrm{H}_{5} \mathrm{Fe}(\mathrm{CO})_{3} \mathrm{O}_{2}-\mathrm{C}-\mathrm{CO}_{2} \cdot->\mathrm{C}=\mathrm{C}< \\
\stackrel{k_{\mathrm{p}}^{\prime}}{\longrightarrow} \pi-\mathrm{C}_{3} \mathrm{H}_{5} \mathrm{Fe}(\mathrm{CO})_{3} \mathrm{O}_{2}-\mathrm{C}-\mathrm{CO}_{2}-\mathrm{C}-\mathrm{C} \cdot \\
2 \pi-\mathrm{C}_{3} \mathrm{H}_{5} \mathrm{Fe}(\mathrm{CO})_{3} \mathrm{O}_{2}-\mathrm{C}-\mathrm{C}-\mathrm{O}_{2} . \\
\stackrel{2 k_{t}^{\prime}}{\longrightarrow} \text { inert compounds. }
\end{gathered}
$$

According to these steps, eq. (C) is con= verted into eq. (E) :

$$
\begin{aligned}
& -d\left[\mathrm{O}_{2}\right] / d t=\left[k^{\prime}{ }_{\mathrm{p}}{k^{\prime}}^{\prime}{ }^{1 / 2} /\left(2 k^{\prime}{ }_{\mathrm{t}}\right)^{1 / 2}\right] \\
& \quad[\alpha \text {-methylstyrene }]^{1.5} \\
& \quad \times\left[\mathrm{O}_{2}\right]^{0.5}\left[\pi-\mathrm{C}_{3} \mathrm{H}_{5} \mathrm{Fe}(\mathrm{CO})_{3} \mathrm{Br}\right]^{0.5} \\
& \text { or }\left[k^{\prime}{ }_{\mathrm{p}} /\left(2 k^{\prime}{ }_{\mathrm{t}}\right)^{1 / 2}\right][\alpha \text {-methylstyrene }] R_{\mathbf{i},{ }_{2}{ }^{1 / 2}}
\end{aligned}
$$

For $\alpha$-methylstyrene, the value of $k_{\mathrm{p}}^{\prime} /$ 
$\left(2{k^{\prime}}^{\prime}\right)^{1 / 2}$ was reported as $1.3 \times 10^{-2} \mathrm{M}^{-1 / 2} \mathrm{~s}^{-1 / 2}$ at $30^{\circ} \mathrm{C}$, and activation energies $\Delta E_{k^{\prime} \mathrm{p}}$ and $\Delta E_{k^{\prime}}$, as 8.07 and $3.07 \mathrm{kcal} / \mathrm{mol}$, respectively. ${ }^{8}{ }^{8}$ Therefore, the value for $k_{\mathrm{p}}^{\prime} /\left(2 k_{\mathrm{t}}^{\prime}\right)^{1 / 2}$ at $50^{\circ} \mathrm{C}$ can be estimated as $2.48 \times 10^{-2} \mathrm{M}^{-1 / 2} \mathrm{~s}^{-1 / 2}$. When $3.86 \mathrm{M}$ of $\alpha$-methylstyrene was oxidized at $50^{\circ} \mathrm{C}$ in presence of $2 \times 10^{-3} \mathrm{M}$ of $\pi-\mathrm{C}_{2} \mathrm{H}_{5} \mathrm{Fe}-$ $(\mathrm{CO})_{3} \mathrm{Br}$, the rate of oxygen absorption was $6.03 \times 10^{-5} \mathrm{Ms}$. Substitution of these values into eq. (E) gives the $R_{\mathrm{i}, 2}$ as $3.97 \times 10^{-7} \mathrm{M} / \mathrm{s}$, in agreement with the reported value $3.2 \times$ $10^{-7} \mathrm{Ms}$ for $R_{\mathrm{i}, 2}$ measured by the inhibitor method.*3) This result also supports the me= chanistic scheme mentioned above. The rate constant $k^{\prime}{ }_{2}$ was calculated as $4.50 \times 10^{-3} \mathrm{M}^{-2} \cdot \mathrm{s}^{-1}$.

The oxidation products consisted of aceto= phenone $(39 \%), \alpha$-methylstyrene oxide $(5.9 \%)$, and polyperoxide (27\%), along with some oligomers of $\alpha$-methylstyrene. The polyperoxide was a transparent rubber-like material, and was identified by IR $\left(\nu_{-o-o-}=1030 \mathrm{~cm}^{-1}\right)$ and elementary analysis (anal. : $\mathrm{C} 72.9, \mathrm{H}$ 6.93; lit. ${ }^{19)}$ : C 73.37, H 6.56) to be an alternating copolymer between $\alpha$-methylstyrene and oxygen (cald. : C 71.95, H 6.67).

Other five kinds of unsaturated substrates

Table-2 Oxidation of unsaturated compounds using $\pi-\mathrm{C}_{3} \mathrm{H}_{5} \mathrm{Fe}(\mathrm{CO})_{3} \mathrm{Br}$ as catalyst.

\begin{tabular}{l|c|c|l}
\hline \multicolumn{1}{c|}{$\begin{array}{c}\text { Unsaturated } \\
\text { compounds }\end{array}$} & $\begin{array}{c}-d\left[\mathrm{O}_{2}\right] / d t \\
\left(\times 10^{6} \mathrm{M} \cdot \mathrm{s}\right)\end{array}$ & $\begin{array}{l}R i^{*} \\
\left(\times 10^{7} \mathrm{M} \cdot \mathrm{s}\right)\end{array}$ & $\begin{array}{l}k^{\prime}{ }^{2} \\
\left(\mathrm{M}^{-2} \cdot \mathrm{s}^{-1}\right)\end{array}$ \\
\hline $\begin{array}{c}c-\text { Methylstyrene } \\
\text { Styrene }\end{array}$ & 60.3 & 3.20 & $4.5 \times 10^{-3}$ \\
Indene & 25.0 & 0.147 & $2.50 \times 10^{-4}$ \\
Butyl methacrylate & 1.50 & 4.71 & $8.19 \times 10^{-3}$ \\
Methyl methacrylate & 2.20 & & \\
Vinyl acetate & 0.60 & & \\
\hline
\end{tabular}

[Unsaturated compd.] : $3.86 \mathrm{M}$,

$\left[\pi-\mathrm{C}_{3} \mathrm{H}_{5} \mathrm{Fe}(\mathrm{CO})_{3} \mathrm{Br}\right]: 2.0 \times 10^{-3} \mathrm{M}$

$\left[\mathrm{O}_{2}\right]: 1 \mathrm{~atm}, 50^{\circ} \mathrm{C}$

* calculated based on $k_{\mathrm{p}} /\left(2 k_{\mathrm{t}}\right)^{1 / 2}$ from literature.

*3) The rate of initiation $R_{\mathbf{i}, 2}$ can be calculated from $R_{\mathrm{i}, 2}=2[$ inhibitor $] / \tau$

in which $\tau$ denotes the induction peoriod in presence of an inhibitor. When concentrations of $\alpha$-methylstyrene and $\pi-\mathrm{C}_{3} \mathrm{H}_{5} \mathrm{Fe}(\mathrm{CO})_{3} \mathrm{Br}$ were $3.86 \mathrm{M}$ and $2.0 \times 10^{-3} \mathrm{M}$, respectively, and the concentration of BMP was $2.50 \times 10^{-4} \mathrm{M}$ or 1.25 $\times 10^{-4} \mathrm{M}$, the rate of initiation was $3.1 \times 10^{-7} \mathrm{M}$ $\mathrm{s}^{-1}$ (induction peorid $=1620 \mathrm{~s}$ ) or $3.2 \times 10^{-7} \mathrm{Ms}^{-1}$ (induction period $=780 \mathrm{~s}$ ), respectively. were also oxidized with $\pi-\mathrm{C}_{3} \mathrm{H}_{5} \mathrm{Fe}(\mathrm{CO}){ }_{3} \mathrm{Br}$ (Table-2). The rates of oxygen absorbed are well compared with the relative rates of oxi= dation initiated by $N, N^{\prime}$-azobis (isobutyroni= trile) (Fig. -5). ${ }^{20}$ ) This means that these sub= strates are also oxidized through the mechanism as mentioned interms of $\alpha$-methylstyrene. The rate constants $k_{2}^{\prime}$ 's were shown in Table-2. The constants seem to have some correlation with electron densities of double bonds of substrates. In other words, the activated oxygen

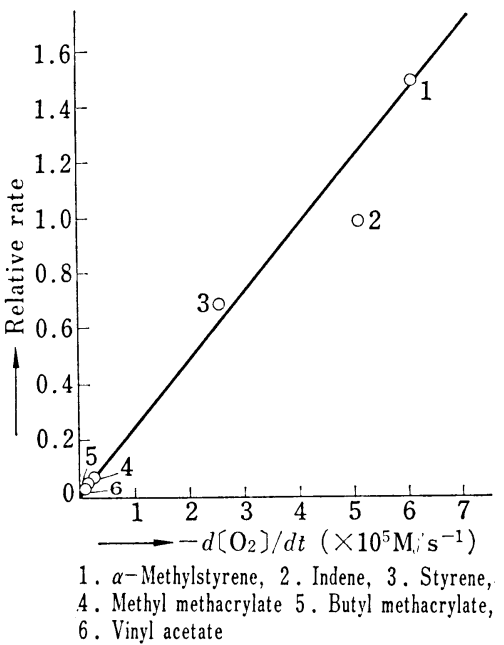

Fig.-5 Relation between relative rates of oxidation and rates of oxidation of olefins by this work.

molecule of $\pi-\mathrm{C}_{3} \mathrm{H}_{5} \mathrm{Fe}(\mathrm{CO})_{3} \mathrm{O}_{2}$ may attack the double bond in an electrophilic manner.

We Wish to express our great thanks to Prof. Teiji Tsuruta for his fruitful discussion to finish this work.

(Received Feb. 3, 1977)

\section{References}

1) G. Wilke, H. Schott, and P. Heimback, Angew. Chem., 79, 62 (1967).

2) J.S. Valentine, Chem. Rev. 73, 253 (1973).

3) Y. Ohkatsu, T. Okuyama, and T. Osa, Yuka= gakv, 27, 142 (1978).

4) J. Blum, H. Rosemann, and E.D. Bergmann, Tetrahedron Lett., 38, 3665 (1967).

5) L.W. Fine, M. Grayson, and V.H. Suggs, $J$. Org. Chem., 45, 786 (1967).

6) J.P. Collmann, K. Kubota, and J. Hosking, J. Am. Chem. Soe., 89, 4809 (1967).

7) T. Hara, Y. Ohkatsu, and T. Osa, Chem. Lett. 1973, 103.

8) T. Hara, Y. Ohkatsu, and T. Osa, Bull. Chem. Soc. Jpn., 48, 85 (1977). 
9) M. Tezuka; O. Sekiguchi, Y. Ohkatsu, and T. Osa, Bull. Chem. Soc. Jpn., 49, 2765 (1976).

10) Y. Ohkatsu, O. Sekiguchi, and T. Osa, Bull. Chem. Soc. Jpn., 50, 701 (1977).

11) Y. Ohkatsu and T. Osa, Bull. Chem. Soc. Jpn.. 50, 2949 (1977).

12) Y. Ohkatsu, T. Takahashi, T. Okuyama, and T. Osa, Yukagaku, 27, 136 (1978).

13) R.A. Plowmann and F.G.A. Stone, Z. Natur. Forsch., 176, 575 (1962).

14) A.N. Nesmeyanov and I.I. Kritskaya, J. Org. Chem.. 14, 387 (1968).

15) F.P. Greenspan, Anal. Chem., 20, 1061 (1948).

16) J.A. Howard and K.U. Ingold, Can. J. Chem., 45, 786 (1967).

17) T. Osa and Y. Ohkatsu, J. Fac. Engng. Univ. Tokyo, A-10, 1 (1972).

18) J.A. Howard and K.U. Ingold, Can. J. Chem.,
44, 1113 (1966).

19) F.R. Mayo and A.A. Miller, J. Am. Chem. Soc., 80, 2480 (1958).

20) F.R. Mayo, J. Am. Chem. Soc., 80, 2497 (1958).

$\pi-\mathrm{C}_{3} \mathrm{H}_{5} \mathrm{Fe}(\mathrm{Co})_{3} \mathrm{Br}$ を触媒とする炭化 水素の酸化

大勝靖一・奥山登志夫・長 哲郎 東京大学工学部合成化学科

$\pi-\mathrm{C}_{3} \mathrm{H}_{5} \mathrm{Fe}(\mathrm{CO})_{3} \mathrm{Br}$ が炭化水素の自動酸化の触媒とな ることが見いだされた。触媒の活性種は酸素錯体, すな わち $\pi-\mathrm{C}_{3} \mathrm{H}_{5} \mathrm{Fe}(\mathrm{CO})_{3} \mathrm{O}_{2}$ であり, $\pi-\mathrm{C}_{3} \mathrm{H}_{5} \mathrm{Fe}(\mathrm{CO})_{3} \mathrm{Br}$ と $\mathrm{O}_{2}$ との反応によって生成することが動力学的に推定 された。この $\pi$-アリル錯体で活性化された酸素は基質 の水素引き抜き反応又汪重結合への付加反応を行らこ とができた。 